Litteratur

1. Iversen 0-E. Bør vi boikotte faglig samarbeid med Kina? Tidsskr Nor Legeforen 2013; 133: 1431

Dette er en redigert versjon av debatten, publisert som rask respons på nett 26.06.2013 http://tidsskriftet.no/article/3034631/

\section{Boikott av faglig samarbeid med Kina}

Kollega Ole-Erik Iversen foreslår i Tidsskriftet nr. 14/2013 (1) at man overveier faglig boikott av Kina. Grunnen er at Kina praktiserer dødsstraff, forfølgelse av regimemotstandere, manglende menneskerettigheter og deres reaksjon på tildelingen av fredsprisen i 2010. Han ser for seg at brev fra ukjente norske leger med ubegripelige navn - snille, lojale undersåtter fra en nasjon som har tildelt fredspris til en mann som ifølge Kinas lover er en forbryter - vil gjøre inntrykk i gigantimperiet. Dette kan bli gøy. Når vi er ferdig med Kina, går vi løs på Pakistan, Afghanistan, store deler av Midtøsten og Afrika - for ikke å snakke om USA, som også har horder av svin på skogen.

Hva med å protestere mot USAs dødsstraff og torturen på Guantanamo? Kongresser i USA utgår, går jeg ut fra. Mye mer nærliggende enn Kina, og mye lettere å bedømme pga. likheter i levesett og kultur. Hva med Israel som bombet i hjel 450 barn i Gaza for et par år siden? Ingen deltakelse på kongresser der! Hva med muslimske lands undertrykkelse og steining av kvinner? I demokratiet India, Kinas nabo, er det selve styresettet og svimlende klasseforskjeller som sørger for at millioner av mennesker hvert år drepes i fattigdomsrelaterte tragedier: sult, feilernæring og trivielle infeksjoner. Kina med sin autoritære styreform har vært i stand til å bringe millioner av mennesker ut av den dypeste misère.

I den beste av tenkelige verdener ville alle vært som oss. Inntil vi kommer dit, er det mange som mener at samtale er en god metode. At gode relasjoner med Kina, utveksling av mennesker begge veier, både leger og andre, direkte samtale med tusenvis av kinesere, i respekt for deres urgamle tradisjoner og moderne økonomiske mirakel, og med åpne muntlige utsagn om vårt syn på menneskerettigheter, vil være en betydelig bedre metode enn provokasjon.

\section{Rolf Seljelid}

ingrid.s.johannessen@gmail.com

Rolf Seljelid (f. 1934) er professor og lege ved Det helsevitenskapelige fakultet, Universitetet i Troms $\emptyset$.

Ingen oppgitte interessekonflikter.

\section{Litteratur}

1. Iversen O-E. Bør vi boikotte faglig samarbeid med Kina? Tidsskr Nor Legeforen 2013; 133: 1431

Dette er en redigert versjon av debatten, publisert som rask respons på nett 29.08.2013 http://tidsskriftet.no/article/3034631/

\section{O.E. Iversen svarer:}

Det er med tilfredshet jeg konstaterer at mitt kommentarinnlegg har medført engasjement. Personlige, direkte kommentarer har bare vært anerkjennende for initiativets poeng og sakens viktighet. Samtidig merker jeg meg at dem som ble særlig utfordret, kollegene som tiljublet Kina for 30-40 år siden, forholder seg tause. Det er vel egentlig mer beklagelig enn overraskende.

De skriftlige debattinnleggene adresserer som ventet dilemmaet: Hva er den beste strategien for å bedre «den urett som blir begått»? Dialog eller konfrontasjon? Svare med samme mynt eller snu det andre kinnet til? Det blir det nok aldri enighet om. Men en bevisstgjøring og penetrasjon av problemstillingen er etter min oppfatning et gode i seg selv.
Seljelids innlegg er engasjert, friskt og poengfylt. Han fremholder at der er urett og overgrep nok i mange land, og elendighet nok til mange boikottaksjoner. Det kan selvfølgelig ikke benektes. Her kunne vi brukt «flasketuten peker på» for å velge land å boikotte. Det treffer imidlertid ikke den situasjon som er mitt utgangspunkt: nemlig når vi skal respondere på kinesiske invitasjoner som omtalt Da kan vi knytte noen kritiske kommentarer til hvorfor vi sier nei takk. Om det er boikott eller ikke, blir et definisjonsspørsmål, men like fullt en anledning til å ytre en mening. Ingen har brakt tilstrekkelige argumenter til å få meg til endre praksis. Kinesiske invitasjoner vil fortsatt bli møtt med: «Nei takk, fordi ...»

Takk for debatten.

\section{Ole-Erik Iversen}

ole.erik.iversen@helse-bergen.no

Ole-Erik Iversen (f. 1945) er professor og overlege ved Institutt for klinisk medisin, Universitetet i Bergen og Kvinneklinikken, Haukeland universitetssykehus.

Ingen oppgitte interessekonflikter.

\section{Leger og trafikksikkerhet - erfaringer fra Møre og Romsdal}

Jørg Mørland påpeker i sin kommentarartikkel om veitrafikkulykker i Tidsskriftet nr. 14/2013 (1) at helsepersonell spiller en viktig rolle i å forebygge trafikkulykker.

I den forbindelse vil jeg dele noen erfaringer vi har gjort oss i Møre og Romsdal. Sommeren 2010 publiserte Helsedirektoratet nye retningslinjer for helsekrav til førerkort. I etterkant økte antall henvendelser til Fylkesmannen om regelverket, og mange leger ønsket kurs om temaet.

Våren 2011 ble det avholdt to kurs beregnet på fastleger og sykehusleger i fylket. Totalt 130 leger møtte opp. Etter kurset opplevde Fylkesmannen en dramatisk økning i antall saker hvor leger meldte fra om personer som ble vurdert til ikke å fylle de helsemessige kravene for å inneha førerkort. Behovet for enklere tilgang til kjørevurdering i regi av Statens vegvesen ble tydelig, og man fikk til en forsøksordning hvor legene i fylket kunne henvise pasienter direkte til kjørevurdering. Fra et svært begrenset antall kjørevurderinger i 2010 opplevde man en økning til i overkant av 170 kjørevurderinger i 2011 og ca. 230 vurderinger i 2012. Min oppfatning er at denne økningen ikke representerer ansvarsfraskrivelse fra legen eller et misbruk av ordningen, men at legene benytter dette som et supplement i de «vanskelige» sakene. Der det klart fremgår at vedkommende pasient ikke fyller helsekravet og heller ikke bør kjøre bil, sendes det direkte melding til Fylkesmannen med begrunnelse.

Den gruppen som etter retningslinjene må gjennomføre kjørevurderinger ved søknad om dispensasjon fra synskravene, har svært lav strykprosent. For de øvrige, som i stor grad er personer med demenslidelser og/eller alderssvekkelse/generell helsesvekkelse, er strykprosenten høy, og kjøring er ikke tilrådelig hos over halvparten. I 2011 og 2012 fikk omkring 1200 personer i Møre og Romsdal tilbakekalt sin førerett på bakgrunn av ikke oppfylte helsekrav. Blant disse dominerer demenslidelser, medikamentbruk og medikament- og rusmisbruk.

Tall fra Statistisk sentralbyrå (2) viser at i snitt ble 6,5 personer pr. 100000 (ca. 16 pr. år) drept årlig i trafikken i vårt fylke i perioden 1999-2009. De siste tre årene har dette tallet vært 2,5 (i snitt 6 pr. år). Hva som ligger bak disse tallene, og om det reelt sett er en endring over tid, er selvsagt usikkert. Uansett er undertegnede overbevist om at legene i fylket gjennom sitt gode «folkehelsearbeid» har forhindret pasienter fra å bli alvorlig skadet eller drept $\mathrm{i}$ trafikken 
og forhindret alvorlig skade eller dødsfall på andre som ferdes i trafikken. Måtte dette gode og svært viktige arbeidet fortsette!

\section{Cato Innerdal}

cato.innerdal@fylkesmannen.no

Cato Innerdal (f. 1979) er assisterende fylkeslege hos Fylkesmannen i Møre og Romsdal.

Oppgitte interessekonflikter: Forfatter har en bistilling som seniorrådgiver i Helsedirektoratet, hvor han arbeider med å revidere gjeldende retningslinjer for helsekrav til førerkort.

\section{Litteratur \\ 1. Mørland J. Kan legen forebygge veitrafikkulykker? Tidsskr Nor Legeforen 2013; 133: 1432. \\ 2. Statistisk sentralbyrå. www.ssb.no/transport-og-reiseliv/statistikker/vtu (5.9.2013).}

Dette er en redigert versjon av debatten, publisert som rask respons på nett 16.08.2013. http://tidsskriftet.no/article/3034667/

\section{Sammenheng mellom korte ph.d.-løp og snevre emnevalg?}

I Tidsskriftet nr. 14/2013 (1) problematiserer Per Vaglum at emnevalg for prøveforelesningen til doktorgradskandidater med årene er blitt snevrere. Kan det ha betydning om doktorgraden er med eller uten pliktår med undervisning? Kan det være at 3-årig ph.d.-utdanning først og fremst er vektlagt som en forskerutdanning, og ikke en lærerutdanning?

Jeg som er eksternt finansiert via helseforetaket i en 3-årig ph.d.stilling, kan vanskelig se at jeg skal bli mer kompetent i pedagogikk ved å holde noen få presentasjoner på konferanser. Alle kandidater planlegger ikke en videre karrierevei innenfor akademia, men som forskere (eller i andre stillinger) på eksterne institusjoner. Sett i lys av det er det kanskje ikke så rart at prøveforelesningen er mer snevert fokusert på det aktuelle fagområdet, fremfor på pedagogikken. Om det er riktig eller galt, er en annen sak.

\section{Per-Jostein Samuelsen}

per-jostein.samuelsen@unn.no

Per-Jostein Samuelsen (f. 1982) er m.sc. pharm., stipendiat ved Regionalt legemiddelinformasjonssenter (RELIS) Nord-Norge, Universitetssykehuset Nord-Norge og Universitetet i Troms $\varnothing$.

Ingen oppgitte interessekonflikter.

\section{Litteratur}

1. Vaglum P. Doktorgradens prøveforelesning har for snevert emnevalg. Tidsskr Nor Legeforen 2013; 133: 1433-4.

Dette er en redigert versjon av debatten, publisert som rask respons på nett 6.7.2013. http://tidsskriftet.no/article/3034723/

\section{P. Vaglum svarer:}

Kollega Samuelsen har dessverre ikke fått tak i poenget med mitt innspill: Det er faglig bredde som skal dokumenteres ved valg av emne. Pedagogisk kompetanse dokumenteres gjennom fremføringen - uansett emne.

\section{Per Vaglum}

per.vaglum@medisin.uio.no

Per Vaglum (f. 1938) er professor dr. med. ved Universitetet i Oslo. Ingen oppgitte interessekonflikter.

Dette er en redigert versjon av debatten, publisert som rask respons på nett 30.7.2013. http://tidsskriftet.no/article/3034723/

\section{P. Samuelsen svarer:}

Takk for presiseringen. Jeg fikk med meg Vaglums hovedpoeng om faglig bredde første gang, men min kommentar var kanskje litt på siden.

Vaglum viser til endret praksis rundt prøveforelesningen. Jeg viste til at vi får stadig flere med 3-årig ph.d.-utdanning og følgelig uten undervisningserfaring, og stilte spørsmål om disse trendene har sammenheng. Det er mulig at det var søkt.

Når prøveforelesningen blant annet er en vurdering av kandidatens pedagogiske ferdigheter, vil nødvendigvis kandidater med ett års undervisningsplikt ha et fortrinn - den pedagogiske kompetansen er neppe lik mellom de to typene kandidater. Videre jobber $33 \%$ av dagens doktorer utenfor universitet og høyskole. Nordisk institutt for studier av innovasjon, forskning og utdanning sier det på denne måten i sin rapport om ph.d.-utdanningen i Norge: «The $\mathrm{PhD}$ is no longer seen as primarily, let alone exclusively, a representation of academic heritage and a breeding ground for the next generation of university teachers and scholars. PhDs are now trained in an effort to sustain growing demands for advanced research competencies in society at large.» (1).

Doktorgrad betyr i dag mer enn å være universitetslærere. Kanskje er det en av forklaringene til utviklingen.

\section{Per-Jostein Samuelsen}

per-jostein.samuelsen@unn.no

Per-Jostein Samuelsen (f. 1982) er m.sc. pharm., stipendiat ved Regionalt legemiddelinformasjonssenter (RELIS) Nord-Norge, Universitetssykehuset Nord-Norge og Universitetet i Tromsø.

Ingen oppgitte interessekonflikter.

Litteratur

1. Thune MT, Kyvik S, Sörlin S et al. PhD education in a knowledge society: an evaluation of PhD education in Norway. NIFU-rapport 25-2012. Oslo: Nordisk institutt for studier av innovasjon, forskning og utdanning, 2012. www.nifu.no/ publications/951985/ [13.8.2013)

Dette er en redigert versjon av debatten, publisert som rask respons på nett 6.7.2013. http://tidsskriftet.no/article/3034723/

\section{Apiksaban - refusjon på blåresept for ikke-valvulær atrieflimmer}

I forbindelse med oversiktsartikkelen Atrieflimmer og hjerneslag i Tidsskriftet nr. 14/2013 (1) vil vi opplyse om at apiksaban fra 1.7.2013 har refusjon på blåresept for indikasjonen ikke-valvulær atrieflimmer på lik linje med de to øvrige nye antikoagulantia som er omtalt i artikkelen.

\section{Anne Hege Aamodt}

anne.hege.aamodt@ous-hf.no

Per Morten Sandset

Dan Atar

Arnljot Tveit

David Russell

Anne-Hege Aamodt (f. 1972) er overlege ved Oslo universitetssykehus. Oppgitte interessekonflikter: Forfatter har mottatt foredragshonorar/ møtegodtgjørelse fra BMS/Pfizer og Boehringer-Ingelheim.

Per Morten Sandset (f. 1956) er lege og forskningsleder ved Klinikk for kreft, kirurgi og transplantasjon, Oslo universitetssykehus.

Oppgitte interessekonflikter: Forfatter har mottatt foredragshonorar fra Boehringer-Ingelheim, Bayer og BMS/Pfizer.

Dan Atar (f. 1959) er lege ved Medisinsk klinikk, Oslo universitetssykehus. Oppgitte interessekonflikter: Forfatter har mottatt foredragshonorar/ konsultasjonshonorar fra Boehringer-Ingelheim, BMS/Pfizer, NycomedTakeda og Bayer. 